\title{
Sinergity of Actors Role for the Development of Tourism Sub-System in Borobudur
}

\author{
Lintang Muliawanti ${ }^{1}$, Moch. Imron Rosyidi ${ }^{2}$, Annis A. Suryaningtyas ${ }^{3}$, Prihatin Dwihantoro ${ }^{4}$ \\ \{lintangmuliawati@ummgl.ac.id $\left.{ }^{1}\right\}$ \\ Universitas Muhammadiyah Magelang, Magelang, Indonesia ${ }^{1,2,3,4}$
}

\begin{abstract}
This study aims to see how the role of CBT Nusantara as the program implementer to maximize the potential of villages as a tourism sub-system of Borobudur. The methodological approach used is descriptive qualitative. Theory of the Role and Community Based Tourism is used to analize the case. The results showed that there were still obstacles in several aspects, especially in making the program, because it had to be adjusted to the potential of each village that had not been well managed. Changing the mindset of rural communities related to the tourism potential development program in Borobudur District is a major challenge for CBT Nusantara. Participatory roles with the characteristics of active people and providing facilities and equal standing so that participation is balanced. Disseminating information, increasing community income, preservation and restoration of natural, human and cultural resources, and encouraging local community participation. The variety of roles to facilitate the community cannot be maximized given the problems in various complex villages. The strategy of Pentahelix synergy launched by the Ministry of Tourism is expected to further maximize the role of CBT Nusantara because tourism development is not only the responsibility of an party but all aspects of ranging from academics, the private sector, the community, the government and the media.
\end{abstract}

Keywords: Role, Community Based Tourism, Tourism

\section{Introduction}

The length of stay of tourists is still a major problem in the tourism sector in Magelang Regency. The head of Disparpora Magelang Regency, Iwan Sutiarso said that the length of the tourist visit in Magelang Regency was only between 2 to 3 hours, or less than half a day, because tourists only visited Borobudur Temple [1]. This causes the tourism sector to be suboptimal in Magelang Regency, which also has an impact on the lack of regional income. If it is optimized, the tourism sector can become a source of regional and even national income. The visit of foreign tourists contributed to foreign exchange receipts of 176-184 trillion rupiah (prognosis), from the 2016 target of 172 trillion rupiahs. The increase in the achievement of foreign exchange actually occurs when foreign exchange from coal and oil and gas commodities tends to decrease [2].

The tourism sector can become a source of regional and even national income if it maximized. The visit of foreign tourists contributed to foreign exchange receipts of 176-184 trillion rupiah (prognosis), from the 2016 target of 172 trillion rupiahs. The increase in the achievement of foreign exchange actually occurs when foreign exchange from coal and oil and gas commodities tends to decrease [2]. 
The program is organized by the Ministry of State-Owned Enterprise (SOEs) with CBT Nusantara as the executor of the assistance activities. This activity collaborated with 20 SOEs companies that developed 20 Balkondes [3]. Various kinds of local products and the uniqueness of each village become a tangible form of community development in the area. Balkondes also becomes a space for the emergence of products such as Bigaran Chocolate, Pottery Academy, Coffee Mejaksingi, etc., making this program provide a different village experience in each Balkondes assistance village. This program also uses the tagline "The Experience Vilage Atmosphere" [4]. This program is a form of implementation of Community-based Tourism by carrying out a concept oriented to the development of rural communities in Borobudur. The role of the community is the key to the successful implementation of this concept. In order to develop Community-based Tourism and increase the success of the optimization of the tourism sector.

The reality of the success of this program in terms of empowerment, is not in line with the main objective to increase the length of tourist visits. This program has been running since 2016 . The reality is that until 2018 this program is still not very significant in increasing the length of stay of tourists [1]. Meanwhile, since the program has run three times there has been a change of managers including PT. TWC, PT. Patra Jasa, and in April 2019 management was handed over to CBT Nusantara under the auspices of the Ministry of SOEs to continue the program of the previous manager. This study aims to, examine about, "the role of CBT Nusantara as program implementers in maximizing the potential of the village as a tourism subsystem of Borobudur".

\section{Literature Review}

\subsection{Role Theory}

The term "role" is taken from the world of theater. In theater, an actor must reflect as a certain figure and in his position as a figure he is expected to behave in a certain way. Role Theory is very closely related to the name of socialization. Some sociologists call socialization a theory of roles. The role according to Soekanto is a dynamic process of status (status) [5]. If a person performs his rights and obligations according to his position, he / she performs a role. The difference between position and role is for the sake of science. The two cannot be separated because one depends on the other and vice versa. This role theory provides a conceptual framework in the study of behavior in organizations. Experts claim that the role "involves a pattern of product creation as opposed to behavior or action".

According to Dougherty \& Pritchard for the Year in Baurer, the theory of cast provides a conceptual framework in the study of behavior in organizations. They claim that the role involves the pattern of product creation as opposed to behavior or action [6]. Role definition is a set of behaviors that are expected by others to be in accordance with the position of a system [7]. According to Soerjono Soekanto, roles are divided into three types, namely "Active Role, an active role of a person in an organization as measured by the contribution it provides," Participatory Role ", the role a person plays due to needs or only at certain times and" Role Passive ", a role that is not carried out by individuals who function as symbols in certain conditions in people's lives. In This Research Role theory is used as an indicator in assessing the performance of CBT Nusantara. 


\subsection{Tourism Villages and Community-based Tourism}

Tourism Village is a form of village that is deliberately built and naturally has the ability to attract tourists because of the potential for natural and cultural attractions [8]. Natural abilities in the form of natural and cultural potential cannot be separated from the role of local communities as the main actors of tourism. Therefore, tourism activities should be activities that come from the community, carried out by the community and the results are intended for the community with the principle of community empowerment.

Tourism development based on community empowerment is an interesting idea, because it is a criticism of the development of conventional tourism (growth-oriented models) that are not in favor of the rights of local communities. Murphy argues that in essence the development of tourism cannot be separated from resources and the uniqueness of the local community which is the main driving element of tourism activities in the form of physical and non-physical elements such as tradition and culture [9]. Tourism should be seen as a community-based activity, known as Community Based Tourism (CBT).

Community Based Tourism (CBT) is a community-based tourism approach, where the community is placed as the main actor with community empowerment in various tourism activities. This has a big impact and benefits for the community, because the main purpose of tourism development is to improve the welfare of the local community. CBT is a tourism concept that considers environmental, social, and cultural sustainability [10]. With the concept of CBT, tourism is managed and owned by the community, with full benefits for the community, with the aim to enable visitors to increase awareness and knowledge about the local community and local wisdom they have.

Based other concept in study development Comunity Based-Tourism by Mohan J. Dutta, Communicating social change. In the process of social change from the perspective of Dutta, it always starts with "listening" [11]. In terms of "communication" and "communicating" are two different things. So, it is not only enough with communication but it must communicate. So that all elements in the development program feel involved in supporting the goals of development.

\section{Method}

This research was conducted with a qualitative descriptive approach with case study methods, by collecting data and observing directly on objects. The approach was chosen because according to the tradition of hermeneutic phenomenology, researchers must be free from subjectivity Techniques used to maintain objectivity, by collecting data from various sources [12]. Data collection was done by observation and interviews with managers of CBT Nusantara, Manager of Balkondes Wanurejo, Balkondes Tuksongo, Balkondes Tanjung Sari (Duta Menoreh), Balkondes Majaksingi, and Balkondes Ngargogondo

\section{Result and Discussion}

\subsection{Operationalization of The Role in The Development of the Borobudur Tourism Sub- System}


The development of tourism villages in the Borobudur region is an effort to prepare the tourism ecosystem. By maintaining local wisdom, Balkondes activities in Borobudur are expected to be able to carry out tourism development such as the Community Based Tourism (CBT) concept above. However, until now the data shows that the length of stay of tourists is still minimal, so that the tourism ecosystem has not been maximally developed.

Currently in the effort to develop tourism in the Borobudur sub-district, the Balkondes implementing facilitator CBT Nusantara. CBT Nusantara itself was formed in April 2019, as a continuation of the PT TWC and SOEs Patra Jasa program. In this study what is seen is the role of CBT Nusantara in the development of balkondes as a subsystem in the Magelang tourism ecosystem.

Departing from Dougherty \& Pritchard's Role Theory (1985) the role capacity of a person, or body can be seen in three categories namely; Active Role, Participatory Role, Passive Role. The operational definition used in this research is focused on the role of CBT Nusantara. From this research, it will be seen how the strategy of CBT Nusantara's role is most effective in developing the tourism ecosystem.

An active role is if all Balkondes development activities come from CBT Nusantara. The participatory role is if all balkondes development activities are based on the collaboration of village and community officials with CBT Nusantara. The passive role is that in the balkondes development activities there is no contribution whatsoever on the part of CBT Nusantara.

In the Community Based Tourism (CBT) approach the role of the facilitator or program implementer must pay attention to community characteristics. Then the role should be adjusted to the characteristics of the community. So as to facilitate the development activities. Chliders [11] said that:

"If you want development to be rooted in humans as development agents and beneficiaries, who will decide for themselves the type of development they can sustain after foreign aid is lost, then you need to be able to communicate with them, you have to give them the opportunity to communicate with one another. and return to the planners in the capital. You have to communicate the techniques they need so they can decide on their own development. If you don't, you will continue to have weak or failed development programs. As simple as that". The most important point in development communication is knowing the character of the audience [11]. The fundamental principle of Development Support Communication Service (DSCS) is Know Your Audience. Then the role of the facilitator should be adjusted in the balalkondes program presented in Figure 1.

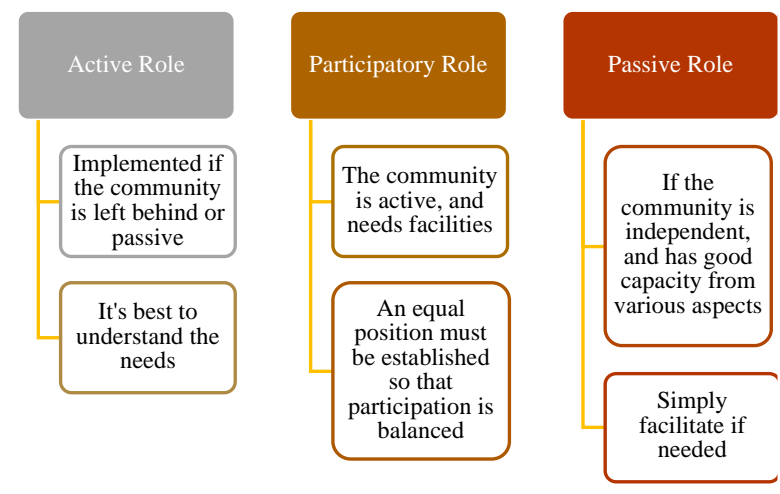

Fig. 1. Execution of an ideal program executed by researchers from various sources 
The formation of the tourism ecosystem in Borobudur through the balkondes program does not necessarily just happen. The process of determining the potential development of 20 balkondes according to Seno, was taken based on the observation of CBT Nusantara for what potentials each village has.

"At first they had the potential for chocolate, but it was not careless. We have to do it so they can run the chocolate well ... How about 20 villages with different thoughts .... " [4].

Based on the results of observations of CBT Nusantara is known for the tourism potential of a number of villages with the balkondes program can be seen in Table 1 .

Table 1. The tourism potential of a number of villages with the Balkondes program

\begin{tabular}{|c|c|c|}
\hline No & Name of Village & Highlights of the Potential Tourism \\
\hline 1. & Borobudur & $\begin{array}{l}\text { Near Borobudur temple, Borobudur Coffee Pot, and classic } \\
\text { transportation tool (Andong and VW) }\end{array}$ \\
\hline 2. & Bumiharjo & Traditional Children Toy \\
\hline 3. & Giritengah & Natural honey cultivation \\
\hline 4. & Karanganyar & Handicraft \\
\hline 5. & Karangrejo & $\begin{array}{l}\text { Organic villages focus on natural resources (Stumbu Acid, Five Acids, } \\
\text { Sendanu Widodaren, Puspitosari Sendang, Cemuris Cultures). }\end{array}$ \\
\hline 6. & Kenalan & Natural view of the plantation \\
\hline 7. & Kembanglimus & Natural view of the plantation \\
\hline 8. & Kebonsari & Bamboo industry \\
\hline 9. & Majaksingi & The coffee plantation is thriving \\
\hline 10. & Ngadiharjo & Fruit farming, rice, and citrus. \\
\hline 11. & Candirejo & Natural view, geological tourism, salty springs \\
\hline 12. & Bigaran & Traditional culinary, agro tourism \\
\hline 13. & Ngargogondo & Handycraft \\
\hline 14. & Giripurno & Etawa goat breeders, waterfalls, tourist parks \\
\hline 15. & Sambeng & Home industry of agriculture product \\
\hline 16. & Tuksongo & Digital Heritage Village \\
\hline 17. & Wanurejo & Experience tourism, handcraft, traditional culinary \\
\hline 18. & Tanjungsari & Tofu Central \\
\hline 19. & Tegalarum & Tobacco, herbs \\
\hline 20. & Wringinputih & Agriculture and natural view \\
\hline
\end{tabular}

\subsection{Synergy of Cbt Nusantara As Balkondes Trustee Partner}

Prosperous and healthy communities are the cornerstone for a successful tourism industry [13]. Community is not the only factor to the success of the tourism industry. There are various indicators if can be synergized properly, will be the key to the success of Community-based Tourism: participation of local community, association and support from inside and outside the community, local ownership, local management and leadership, communication and interaction between stakeholders, preservation of tourism resources, distribution of benefit, quality of life, and the scale of tourist's satisfaction and tourism development [14].

Balkondes is a form of community empowerment by SOEs through the activation of the tourism-based rural economic potential. With a background to develop rural economic growth and empower people in the Borobudur region. Through 20 Balkondes in 20 villages in 
Borobudur District, it is hoped that it can accelerate the economy of the communities around Borobudur by increasing knowledge, skills, product innovation, and income. To achieve these expectations, CBT Nusantara was formed by the Ministry of SOEs.

The role of CBT Nusantara is to guard balkondes standardization, which is to market and introduce balkondes, improve service quality, as well as neat organizational and administrative governance. There are three incubation stages in balkondes, such as: 1) the economic activation scheme of rural communities, namely to open market access and increase human resource capacity, finance, production and marketing; 2) start-up, where sponsoring SOEs only contribute $25 \%$ while $75 \%$ is entirely the responsibility of Badan Usaha Milik Desa (BUMDes); 3 ) the community is ready to do entrepreneurship independently [15]. Accompaniment, CBT Nusantara is still at the initial level. As of the inauguration of CBT Nusantara as a balkondes management agency by the Ministry of SOEs in April 2019, there were two events held, which are Balkonjazz Festival and Balkonbike in collaboration with the Indonesian Journalists Association aimed at marketing functions and expanding market access by increasing balkondes brand awareness.

Balkonjazz is a design of economic activation of rural communities, by opening market access and marketing through festivals that combine local wisdom with music. By organizing Balkonjazz, tourists are expected to be able to increase the length of stay by utilizing homestay facilities and a variety of convenient facilities plus experience to experience the local potential in the area around Balkondes. With the Balkonjazz event, the number of visits to Borobudur has been proven by all lodging in 20 full balkondes, even homestays and hotels owned by local residents until large hotels are fully booked by visitors who incidentally are those who come to Magelang to attend the event of Balkonjazz. Balkonjazz helped boost the economy by providing space to encourage the potential and local wisdom where the surrounding community could promote and sell their homemade products in a venue provided as the balcony market [4]. But it is different from the Balkonbike event, where increased marketing can only be seen in the aspect of increased engagement in the media, both electronic and digital.

The Ministry of Tourism created the concept of integration of tourism Pentahelix. The assumption is that there are five elements of strength stakeholders who will support the success of tourism if they work together. The five stakeholders are Academics, Business, Government, Society, and Media [15]. Thus in the future it is expected that tourism development is not only the responsibility of one party, but there must be synergy between parties, not just the role of CBT Nusantara in the development of Balkondes in Borobudur District.

Society as a major component in community-based tourism development has a very important role in tourism development, especially for Balkondes. Participatory roles with the characteristics of active people and providing facilities and equal standing so that participation is balanced. With the dissemination of information, increasing community income, preservation and restoration of natural, human and cultural resources, and encouraging local community participation. But it is unfortunate, that the synergy of the community is still not optimal. Whereas the CBT concept carried out by Balkondes pays attention to aspects of community involvement, accentuates the traditions of the local community, the authenticity of the regional potential, the value of local wisdom, and the conservation of carrying capacity [9]. Community participation in development is determined by three main elements, namely the opportunity given to the community to participate, the community's willingness to participate and the ability of the community to participate [16]. The opportunity is given fully to the community, but there is an inequality in mastery of the balkondes themselves.

In some balkondes that already have an advanced potential such as in Balkondes Wanurejo, Karangrejo, Tuksongo. The advance potential is inseparable from the factor of the people who 
already have advance village potential. But in some Balkondes it has been considered torpid because of the lack of community roles. The role of academics in Balkondes is still minimal. While the role of academics is very important in providing views and analysis based on data in the field regarding the level of development and also the right formula to advance balkondes as the wheels of tourism and economy in Borobudur District through various research, analysis and human resource development. Collaboration with the government as regulator, the private sector to the media as the mouthpiece of tourism coverage is still fairly minimal.

Originated from these problems, in the nature study of development communication in addition to focusing on participation. An approach that can be used is an attempt at social change. This effort can be done by starting the activity by "hearing of the needs" that exist in the community [11]. After listening, policy makers can conduct studies and adjustments in implementing a development program. It makes the public has a stake in every activity of development. The development in social change can be seen in Figure 2.

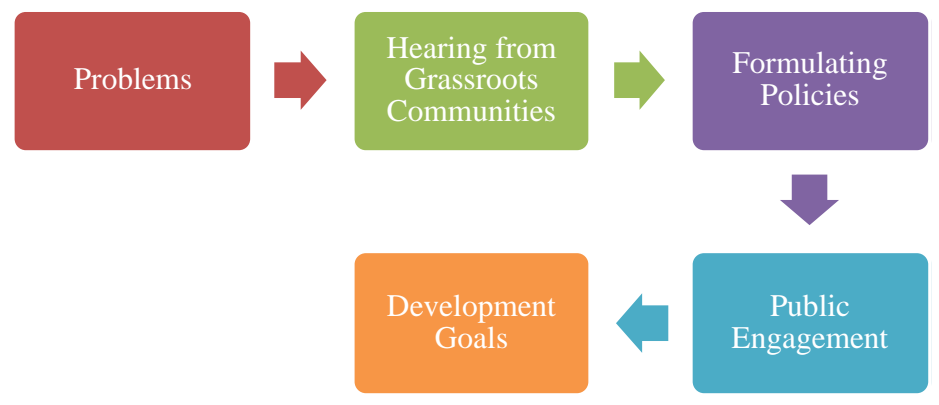

Fig. 2. Development in social change

\section{Conclusion}

Balkondes is a program that adapts the concept of Community-based Tourism with community engagement and civilization. By ensuring that the ownership and management of transparent balkondes is expected to increase the economic potential and local wisdom of the Borobudur community. The participatory role carried out by CBT Nusantara, by implementing an economic activation scheme for rural communities, namely to open market access and increase human resource, financial, production and marketing capacity. The community as the main focus of Balkondes is still not ready in terms of resources and potential. The existence of a monopoly of power because governance is not evenly distributed in Balkondes is the cause of the death of several Balkondes. The variety of roles to facilitate the community cannot be maximized given the problems in various complex villages. The participatory role carried out by CBT Nusantara for the management of 20 Balkondes in Borobudur District will surely stagger if it runs alone. The concept of the Pentahelix Tourism Integration proclaimed by the Ministry of Tourism as a solution is in fact still in jeopardy, where the community as the prime mover, the government as a regulator, academics, the private sector and the media are still not synergizing to the maximum. 


\section{Acknowledgement}

The research was funded by LPPM Universitas Muhammadiyah Magelang.

\section{References}

[1] beritamagelang.id, "Disparpora : Lama Kunjung Wisatawan Di Kabupaten Magelang 2-3 Jam Saja," Diskominfo Kabupaten Magelang, 6 Juli 2018. [Online]. Available: http://beritamagelang.id/disparpora-kabupaten-magelang-nilai-lama-kunjung-wisatawan-dikabupaten-magelang-2-3-jam-saja. [Accessed 20 Agustus 2019].

[2] kementerian pariwisata, "Laporan Akuntabilitas Konerja Kementerian Pariwisata tahun 2016," Biro Perencanaan dan Keuangan Sekretariat Kementerian, Jakarta, 2017.

[3] balkondesborobudur.com, "Tentang Kami: Balkondes Borobudur," PT. Taman Wisata Candi Borobudur, Prambanan dan Ratu Boko, 2017. [Online]. Available: http://balkondesborobudur.com/tentang-kami/. [Accessed 20 Agustus 2019].

[4] Seno, Interviewee, Manajer PT. Manajemen CBT Nusantara. [Interview]. 23 Agustus 2019.

[5] S. Soekanto, Peranan, Sosiologi Suatu Pengantar, Jakarta: Rajawali Pers, 2009, pp. 212-213.

[6] J. C. Bauer, Role Ambiguity and Role Clarity: A Comparison of Attitudes in Germany and the United States., Clermont: University of Cincinnati, 2003.

[7] B. Kozier, Peran dan Mobilitas Kondisi Masyarakat, Jakarta: Penerbit Gunung Agung, 2008.

[8] Y. K. Sari, "Pendampingan berkelanjutan terhadap Pengembangan Pariwisara Desa Selopamioro," Bakti Budaya, vol. 2, p. 60, 1 April 2019.

[9] B. Sunaryo, Kebijakan Pengembangan Destinasi Pariwisata Konsep dan Aplikasinya di Indonesia, Yogyakarta: Gava Media, 2013.

[10] P. Suansri, Community Based Tourism Handbook, Thailand: Responsible Ecological Social TourREST, 2003.

[11] M. Dutta, Communicating Social Change: Structure, Culture, and Agency, London: Routledge, 2011.

[12] W. Neuman, Metodologi Penelitian Sosial: Pendekatan Kualitatif dan Kuantitatif, Jakarta: PT. Indeks, 2013.

[13] K. M. Haywood, "Responsible and responsive tourism planning in the community," Tourism Management, vol. 9, no. 2, pp. 105-118, 1988.

[14] T. Vajirakachorn, Determinants of Success for Community-Based Tourism: The Case of Floating Markets in Thailand, USA: Texas A\&M University, 2011.

[15] Y. Prakasa, "Urban Tourism Based on Social Capital Development Model," Eurasia: Economics \& Business, vol. 1, pp. 37-42, 2019.

[16] A. Theresia, K. Andini, P. Nugraha and T. Mardikanto, "Pembangunan Berbasis Masyarakat," Alfabeta, Bandung, 2014

[17] S. Badgare and R. Jain , "Measuring Retail Customer Experience," Interational Journal of Retail \& Distribution Management, vol. 41, no. 10, pp. 790-804, 2013. 